\title{
Influence of cement type on carbonation of concrete mixtures
}

\author{
Christos Tassos ${ }^{1,}$, , Kosmas Sideris ${ }^{1}$, Alexandros Chatzopoulos ${ }^{1}$, Nikolaos Pistofidis ${ }^{2}$, and \\ Emmanouil Chaniotakis ${ }^{2}$ \\ ${ }^{1}$ Laboratory of Building Materials, Democritus University of Thrace, Xanthi, 67100 Greece \\ ${ }^{2}$ TITAN Cement Company, Kamari Plant, Elefsina 19200 Greece
}

\begin{abstract}
This research aims to investigate the influence of cement type to carbonation. For this purpose mixtures of four different cement mortars and eight different concretes that have been prepared with four different cements were left exposed for one year in open air in northern Greece. Results indicate that the type of cement influences the carbonation rate. Concrete mixtures produced according to the definitions of EN 206 standard perform lower service life against carbonation induced corrosion if the choice of the cement type is not carefully examined.
\end{abstract}

\section{Introduction}

The durability of concrete constructions is an important issue these days with huge economic, social and environmental impact. This problem was to be solved by the new regulations which use restrictions on composition according to the environmental category, in which the construction is exposed.

The exposure category of constructions is defined with clarity in EN 206-1, but the severity of environmental exposure depends on the local climate conditions. In recent times, efforts have been made to correlate the severity of exposure against carbon dioxide with meteorological data, mainly annual fluctuations in the relative humidity of the atmosphere. However, intense fluctuations in humidity and high average annual temperatures accelerate the carbonation. Another important factor is the type of the cement used. According to EN 206 , in the case of exposure to carbonation, there are no predictions for the use of different types of cement.

This research aims to investigate the influence of cement type to carbonation. For this purpose mixtures of four different cement mortars and eight different concretes that have been prepared with four different cements were left exposed for one year in open air in northern Greece. Results indicate that the type of cement influences the carbonation rate. Concrete mixtures produced according to the definitions of EN 206 standard perform lower service life against carbonation induced corrosion if the choice of the cement type is not carefully examined.

\footnotetext{
*Corresponding author: ctassos@civil.duth.gr
} 


\section{Experimental program}

Four different cement mortars and eight different concretes were produced. The cement mortars produced according to the European Standard EN 196-1 [1]. The concrete mixtures belonged in the strength classes C25/30 and C30/37 according to EN206-1 [2]. All concretes were prepared using four different cements, CEM I 42.5R, CEM II/A-M(P-LL) 42.5N, CEM II/B-M(W-P-LL) $32.5 \mathrm{~N}$ and CEM II/(B-LL) $32.5 \mathrm{~N}$. In the first four concrete mixtures, CEM I 42.5R or CEM II 42.5 (A-M)N cement was exclusively used for the two strength classes mentioned above. In the remaining four, a cement combination of CEM II/B-M(W-P-LL) $32.5 \mathrm{~N}$ or CEM II (B-LL) $32.5 \mathrm{~N}$ was used along with CEM CEM II/A-M(P-LL)42.5N. Coarse aggregates consisted of crushed granite with a maximum size of $32 \mathrm{~mm}$. The fine aggregate used, were crashed and natural silicate sand. High range water reducing carboxylic ether polymer admixture was added at different dosages to achieve the desired workability. The chemical analysis of the cements used is shown in Table 1.

Table 1. Chemical analysis of used cements.

\begin{tabular}{|c|c|c|c|c|}
\hline & CEM I 42.5 R & $\begin{array}{c}\text { CEM II/A-M } \\
\text { (P-LL) 42.5N }\end{array}$ & $\begin{array}{c}\text { CEM I/B-M } \\
\text { (W-P-LL) } \\
32.5 \mathrm{~N}\end{array}$ & $\begin{array}{c}\text { CEM II (B-LL) } \\
32.5 \mathrm{~N}\end{array}$ \\
\hline $\mathrm{SiO}_{2}$ & 20.86 & 23.85 & 28 & 14.4 \\
\hline $\mathrm{AI}_{2} \mathrm{O}_{3}$ & 5.38 & 5.22 & 9 & 5.1 \\
\hline $\mathrm{Fe}_{2} \mathrm{O}_{3}$ & 2.73 & 4.13 & 5.5 & 2.4 \\
\hline $\mathrm{CaO}$ & 60.88 & 58.2 & 48 & 62.5 \\
\hline $\mathrm{MgO}$ & 2.31 & 3.2 & 2.2 & 1.6 \\
\hline $\mathrm{SO}_{3}$ & 3.13 & 3.3 & 3.2 & 3.2 \\
\hline $\mathrm{K}_{2} \mathrm{O}$ & 1.93 & 0.68 & 1.5 & 0.1 \\
\hline $\mathrm{Na}_{2} \mathrm{O}$ & - & 0.32 & 0.5 & 0.2 \\
\hline $\mathrm{TiO}_{2}$ & - & 0.24 & - & - \\
\hline $\mathrm{P}_{2} \mathrm{O}_{5}$ & - & 0.06 & - & - \\
\hline $\mathrm{SrO}$ & - & 0.03 & - & - \\
\hline $\mathrm{Cr}_{2} \mathrm{O}_{3}$ & - & 0.02 & - & - \\
\hline $\mathrm{ZnO}$ & - & 0.01 & - & - \\
\hline $\mathrm{MnO}$ & - & - & - & 3.05 \\
\hline $\mathrm{Specific}$ weight & 3.1 & 3.1 & 3.15 & \\
\hline
\end{tabular}

Standard type of sand was used in cement mortar mixes, while gravel $(2-16 \mathrm{~mm})$ and rubble $(8-32 \mathrm{~mm})$ were used in the concrete mixes, resulted from crushing of natural rock in a crusher. The proportions as well as the properties of the fresh mixtures are presented for all concrete and cement mortars prepared in Tables 2 and 3.

Table 2. Mix design characteristics of concrete mixtures prepared.

\begin{tabular}{|l|c|c|c|c|c|c|c|c|}
\hline $\begin{array}{l}\text { Mix } \\
\text { design }\end{array}$ & $\begin{array}{c}\text { C 25/30 } \\
\text { CEM I } \\
42.5\end{array}$ & $\begin{array}{c}\text { C 30/37 } \\
\text { CEM I } \\
42.5\end{array}$ & $\begin{array}{c}\text { C 25/30 } \\
\text { CEM II } \\
42.5\end{array}$ & $\begin{array}{c}\text { C } \\
\begin{array}{c}\text { C } / 37 \\
\text { CEM II } \\
42.5\end{array}\end{array}$ & $\begin{array}{c}\text { C 25/30 } \\
\text { Mixed }\end{array}$ & $\begin{array}{c}\text { C 30/37 } \\
\text { Mixed }\end{array}$ & $\begin{array}{c}\text { C25/30 } \\
\text { Mixed }\end{array}$ & $\begin{array}{c}\text { C30/37 } \\
\text { Mixed }\end{array}$ \\
\hline $\mathrm{kg} / \mathrm{m}^{3}$ & $\mathrm{C} 1$ & $\mathrm{C} 2$ & $\mathrm{C} 3$ & $\mathrm{C} 4$ & $\mathrm{C} 5$ & $\mathrm{C} 6$ & $\mathrm{C} 7$ & $\mathrm{C} 8$ \\
\hline $\begin{array}{l}\text { CEM I } \\
42.5\end{array}$ & 300 & 350 & 0 & 0 & 0 & 0 & 0 & 0 \\
\hline
\end{tabular}




\begin{tabular}{|l|c|c|c|c|c|c|c|c|}
\hline $\begin{array}{l}\text { CEM II } \\
42.5\end{array}$ & 0 & 0 & 300 & 350 & 150 & 200 & 150 & 200 \\
\hline $\begin{array}{l}\text { CEM II } \\
32.5\end{array}$ & 0 & 0 & 0 & 0 & 150 & 150 & 0 & 0 \\
\hline $\begin{array}{l}\text { CEM II } \\
32.5 \text { (B- } \\
\text { LL)N }\end{array}$ & 0 & 0 & 0 & 0 & 0 & 0 & 150 & 150 \\
\hline $\begin{array}{l}\text { River } \\
\text { Sand }\end{array}$ & 400 & 400 & 400 & 400 & 400 & 400 & 400 & 400 \\
\hline $\begin{array}{l}\text { Crashed } \\
\text { Sand }\end{array}$ & 500 & 500 & 500 & 500 & 500 & 500 & 500 & 500 \\
\hline Gravel & 270 & 270 & 270 & 270 & 270 & 270 & 270 & 270 \\
\hline Rubble & 630 & 630 & 630 & 630 & 630 & 630 & 630 & 630 \\
\hline Water & 180 & 175 & 180 & 175 & 180 & 175 & 180 & 175 \\
\hline Sup/er & 1.17 & 1.4 & 1.17 & 1.4 & 1.17 & 1.4 & 1.17 & 1.4 \\
\hline $\begin{array}{l}\text { Retarde } \\
\text { r }\end{array}$ & 0.56 & 0.69 & 0.56 & 0.69 & 0.56 & 0.69 & 0.56 & 0.69 \\
\hline W/C & 0.6 & 0.5 & 0.6 & 0.5 & 0.6 & 0.5 & 0.6 & 0.5 \\
\hline $\begin{array}{l}\text { Slump } \\
\text { (cm) }\end{array}$ & 16 & 17 & 22 & 15 & 18.5 & 21 & 15 & 15 \\
\hline
\end{tabular}

Table 3. Mix design characteristics of cement mortars prepared.

\begin{tabular}{|l|c|c|c|c|}
\hline Mix design & CEM I 42.5R & $\begin{array}{c}\text { CEM II/A-M(P- } \\
\text { LL) 42.5N }\end{array}$ & $\begin{array}{c}\text { CEM II/B-M (W- } \\
\text { P-LL) 32.5N }\end{array}$ & $\begin{array}{c}\text { CEM (B-LL) II } \\
32.5 \mathrm{~N}\end{array}$ \\
\hline gr/1,7lt & M1 & M2 & M3 & M4 \\
\hline CEM I 42.5 & 450 & 0 & 0 & 0 \\
\hline CEM II 42.5 & 0 & 450 & 0 & 0 \\
\hline CEM II 32.5 & 0 & 0 & 450 & 0 \\
\hline $\begin{array}{l}\text { CEM II 32.5 } \\
\text { (B-LL) }\end{array}$ & 0 & 0 & 0 & 450 \\
\hline Sand & 1350 & 1350 & 1350 & 1350 \\
\hline Water & 225 & 225 & 225 & 225 \\
\hline W/C & 0.5 & 0.5 & 0.5 & 0.5 \\
\hline flow $(\mathrm{cm})$ & 13.5 & 13.5 & 14 & 14 \\
\hline
\end{tabular}

The cement mortar specimens were prisms 40x40x160mm, while concrete specimens prepared were $150 \mathrm{~mm}$ edge cubes and cylinders $60 \times 100 \mathrm{~mm}$. The cylindrical and the prism specimens were used to measure carbonation depth. These specimens were maintained in a curing chamber $\left(\mathrm{T}=20^{\circ} \mathrm{C}, \mathrm{RH}>98 \%\right)$ for 3 days and then placed in a laboratory environment until the age of 28 days. After this age, a set of specimens were placed into the accelerating carbonation chamber $\left(\mathrm{T}=20^{\circ} \mathrm{C}\right.$, relative humidity $\left.=55 \%, \mathrm{CO}_{2}=1 \%\right)$, while the rest of them were exposed to the outside open air space of the laboratory. This environment corresponds to the exposure class XC4 according to EN 206. All carbonation specimens remained in the exposure environment - accelerated carbonation chamber or open air environment- until the test age. Specimens used for compressive strength measurements were cured in the curing room until the age of the test. 


\section{Experimental results and discussion}

\subsection{Compressive strength}

The compressive strength was measured for all concrete and cement mortar mixtures at ages of 2, 7 and 28 days. These values are shown in Tables 4 and 5 and in Figures 1 and 2.

Table 4. Compressive strength $(\mathrm{MPa})$ of concretes prepared.

\begin{tabular}{|c|c|c|c|c|c|c|c|c|}
\hline$(\mathrm{MPa})$ & $\mathrm{C} 1$ & $\mathrm{C} 2$ & $\mathrm{C} 3$ & $\mathrm{C} 4$ & $\mathrm{C} 5$ & C6 & C7 & C8 \\
\hline $\mathrm{fc}_{2}$ & 26.4 & 30 & 23.9 & 24 & 18.1 & 22.7 & 15.3 & 22.7 \\
\hline $\mathrm{fc}_{7}$ & 36.1 & 50.4 & 32.7 & 39.7 & 24.3 & 34.5 & 22.4 & 32.0 \\
\hline $\mathrm{fc}_{28}$ & 46.1 & 58.7 & 39.7 & 47.6 & 35.0 & 43.3 & 32.5 & 40.2 \\
\hline
\end{tabular}

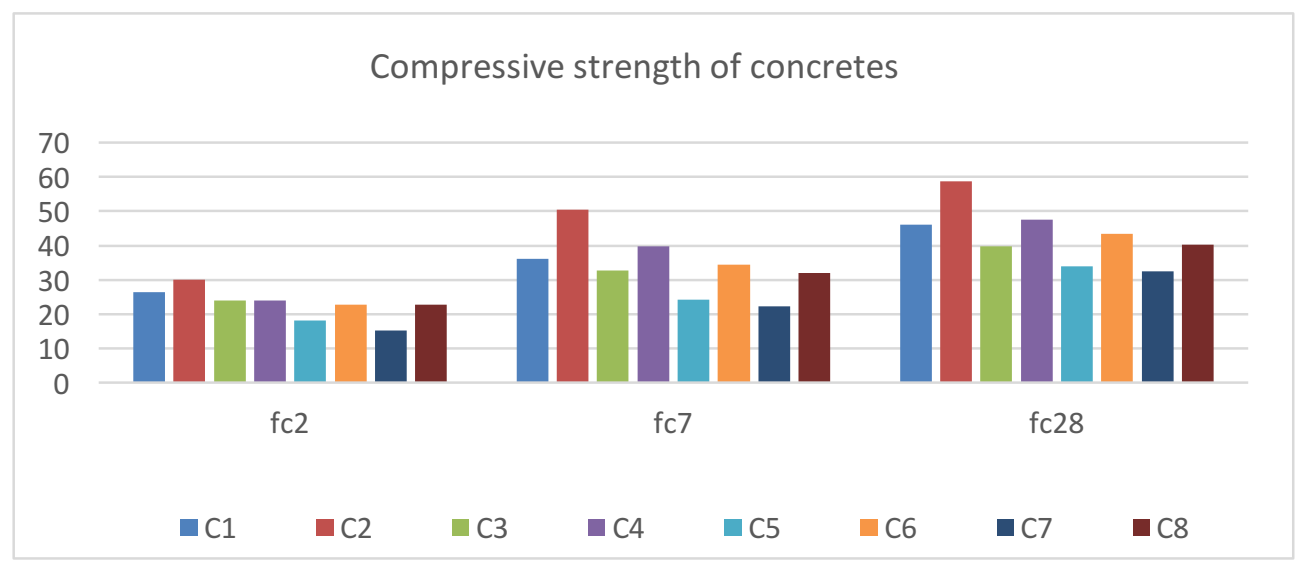

Fig. 1. Compressive strength of concretes $(\mathrm{MPa})$.

Table 5. Compressive strength (MPa) of cement mortars.

\begin{tabular}{|c|c|c|c|c|}
\hline$(\mathrm{MPa})$ & $\mathrm{M} 1$ & $\mathrm{M} 2$ & $\mathrm{M} 3$ & $\mathrm{M} 4$ \\
\hline $\mathrm{fc}_{2}$ & 25.7 & 18.8 & 11.8 & 11.1 \\
\hline $\mathrm{fc}_{7}$ & 38.4 & 30.0 & 21.9 & 20.6 \\
\hline $\mathrm{fc}_{14}$ & 52.6 & 40.6 & 30.0 & 28.1 \\
\hline $\mathrm{fc}_{28}$ & 54.4 & 48.1 & 42.3 & 41.3 \\
\hline
\end{tabular}




\section{Compressive strength of cement mortars}

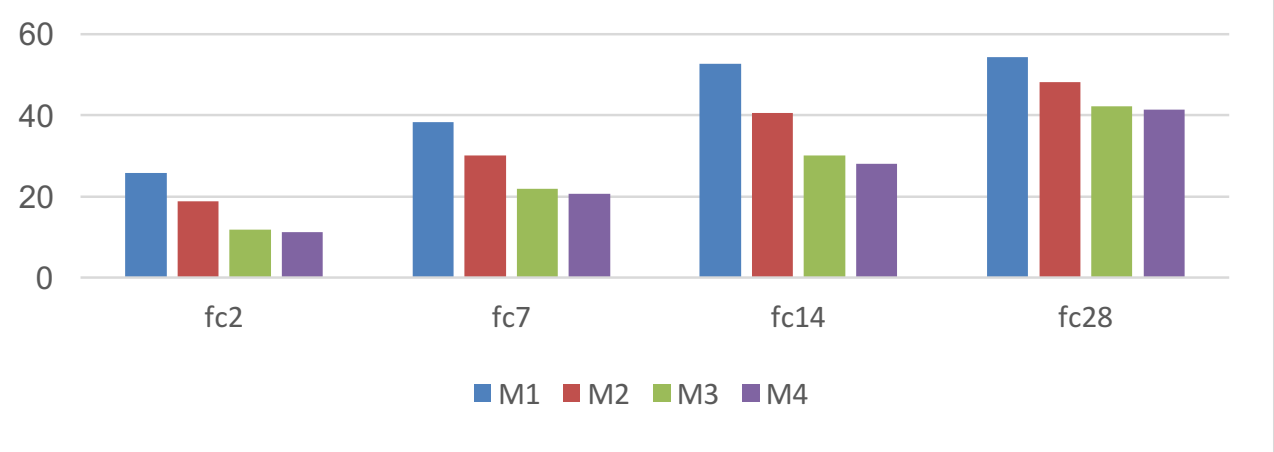

Fig. 2. Compressive strength of cement mortars (MPa).

It is well shown that all mixtures prepared develop the compressive strength needed in order to fulfill the strength requirements of their class according to EN206. Mixture C7 was the exception to this rule. The use of CEM II/B-M (W-P-LL) $32.5 \mathrm{~N}$ and CEM II(B-LL)32.5N cements in combination with high $\mathrm{w} / \mathrm{c}$ ratio resulted to lower compressive strength values at the age of 28 days.

\subsection{Carbonation depth}

The carbonation depth was measured by spraying the freshly broken surfaces of the samples with a phenolphthalein [4] indicator according to the procedure described in Standard EN 14630 [3]. The carbonation depth of all mixtures is shown in Tables 6 to 9.

Table 6. Accelerated carbonation depth of concretes prepared.

\begin{tabular}{|c|c|c|c|c|c|c|c|c|}
\hline Carbonation $(\mathrm{mm})$ & $\mathrm{C} 1$ & $\mathrm{C} 2$ & $\mathrm{C} 3$ & $\mathrm{C} 4$ & $\mathrm{C} 5$ & $\mathrm{C} 6$ & $\mathrm{C} 7$ & C8 \\
\hline 28 days & 3.5 & 3.0 & 4.3 & 3.1 & 8.1 & 4.5 & 10.4 & 6.5 \\
\hline 56 days & 5.3 & 4.6 & 7.1 & 4.8 & 12.6 & 7.4 & 16.3 & 9.9 \\
\hline
\end{tabular}

Table 7. Accelerated carbonation depth of cement mortars.

\begin{tabular}{|c|c|c|c|c|}
\hline Carbonation $(\mathrm{mm})$ & M1 & M2 & M3 & M4 \\
\hline 28 days & 2.5 & 2.3 & 5.8 & 6.5 \\
\hline 56 days & 3.5 & 3 & 8.1 & 9.4 \\
\hline 90 days & 4.3 & 3.8 & 10.3 & 11.8 \\
\hline 120 days & 4.8 & 4.3 & 11.7 & 13.9 \\
\hline 180 days & 5.8 & 5.3 & 14.0 & 17.0 \\
\hline
\end{tabular}

Table 8. Natural carbonation depth of concretes prepared.

\begin{tabular}{|c|c|c|c|c|c|c|}
\hline Carbonation $(\mathrm{mm})$ & $\mathrm{C} 1$ & $\mathrm{C} 2$ & $\mathrm{C} 3$ & $\mathrm{C} 4$ & C5 & C6 \\
\hline 6 months & 3.0 & 2.5 & 3.3 & 2.8 & 5.9 & 3.3 \\
\hline 9 months & 4.2 & 3.4 & 4.5 & 3.8 & 7.9 & 4.3 \\
\hline 12 months & 5.2 & 4.1 & 5.5 & 4.9 & 9.5 & 5.3 \\
\hline
\end{tabular}


Table 9. Natural carbonation depth of cement mortars.

\begin{tabular}{|c|c|c|c|c|}
\hline Carbonation $(\mathrm{mm})$ & M1 & M2 & M3 & M4 \\
\hline 3 months & 0.5 & 0.6 & 1.5 & 1.9 \\
\hline 6 months & 0.9 & 0.8 & 2.5 & 3.0 \\
\hline 9 months & 1.0 & 0.9 & 2.9 & 3.5 \\
\hline 12 months & 1.1 & 1.0 & 3.3 & 3.9 \\
\hline
\end{tabular}

The influence of cement type on the carbonation resistance of mixtures is clearly displayed on Tables 7 and 8 . Both mortars and concretes prepared with type II cements found to be more vulnerable against carbonation. This vulnerability increased in mixtures $\mathrm{C} 5$ and C6 produced with combinations of CEM II 45.2 and CEM II32.5 cements. The higher pozzolanic content of these mixtures resulted to higher carbonation depths measured. The carbonation depth measured on mixture $\mathrm{C} 5$ produced with higher w/c ratio was almost twice the one performed by mixtures $\mathrm{C} 1$ and $\mathrm{C} 3$ (Table 6). Increased vulnerability of blended cement concretes produced with higher $\mathrm{w} / \mathrm{c}$ ratios is in accordance of findings of other researches $[5,6]$.

Carbonation rate was further identified by calculating the carbonation coefficient $\mathrm{k}$ of concretes. These values were derived from linear regression between the values measured until the age of one year. The coefficients $\mathrm{k}$ calculated for all concrete and mortar mixtures prepared are demonstrated on Tables 10, 11 and figures 3 and 4 respectively.

Service life against carbonation was assessed by adopting the following formula:

$$
\mathrm{x}=\mathrm{k} \cdot \mathrm{t}^{0.5}
$$

where $\mathrm{k}$ is the carbonation coefficient expressed in $\left(\mathrm{mm} / \mathrm{year}^{0.5}\right)$ and $\mathrm{t}$ is the hydration time expressed in years. [7].

Table 10. Coefficient $\mathrm{k}$ of concretes.

\begin{tabular}{|c|c|c|c|c|c|c|}
\hline & $\mathrm{C} 1$ & $\mathrm{C} 2$ & $\mathrm{C} 3$ & $\mathrm{C} 4$ & $\mathrm{C} 5$ & $\mathrm{C} 6$ \\
\hline $\mathrm{k}$ & 5.0138 & 4.0007 & 5.3382 & 4.6463 & 9.2897 & 5.1654 \\
\hline
\end{tabular}

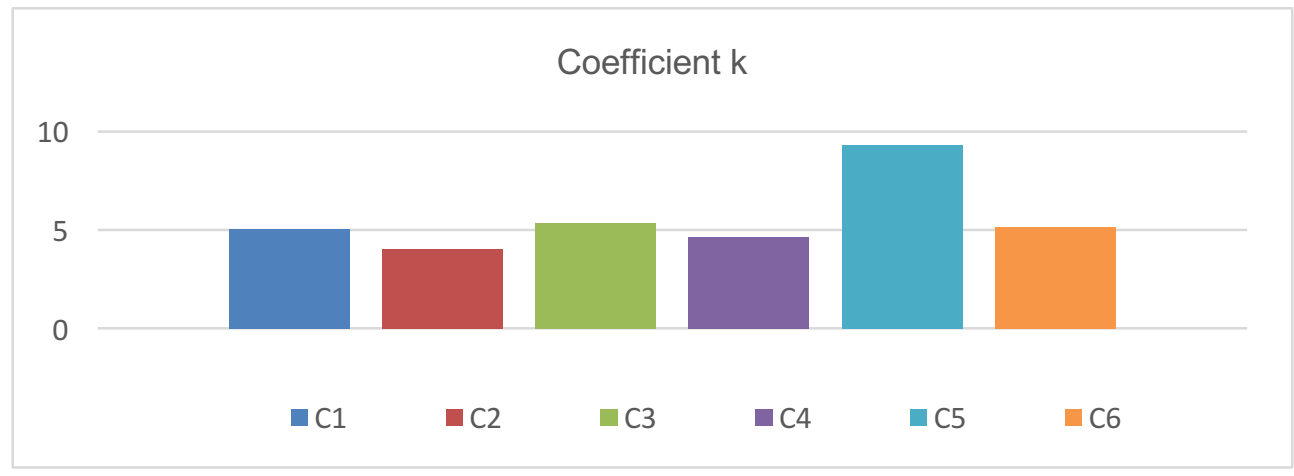

Fig.3. Coefficient k of concretes. 
Table 11. Coefficient k of cement mortars.

\begin{tabular}{|c|c|c|c|c|}
\hline & M1 & M2 & M3 & M4 \\
\hline $\mathrm{k}$ & 1.1474 & 1.0093 & 3.3707 & 3.9964 \\
\hline
\end{tabular}

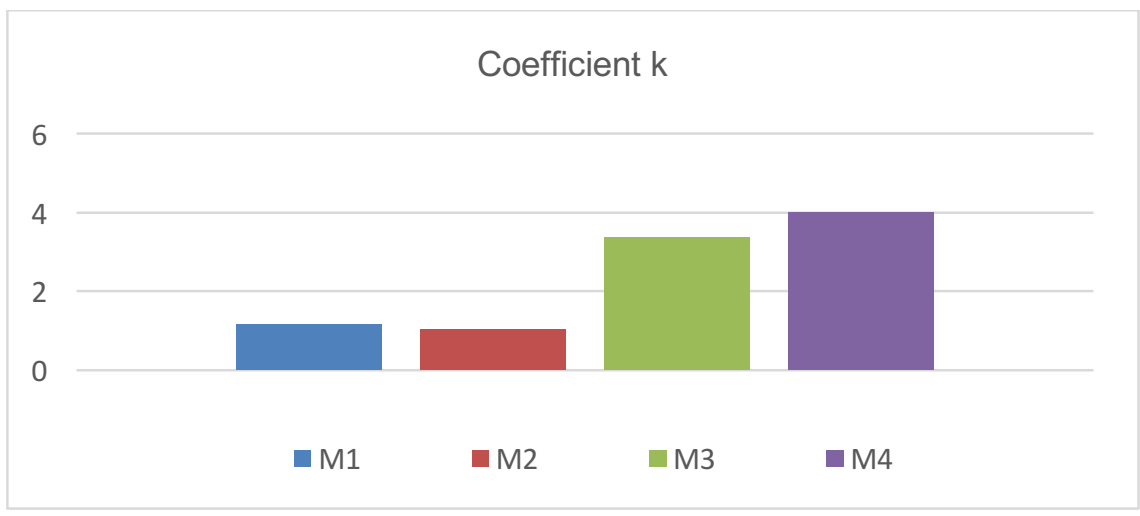

Fig. 4. Coefficient $\mathrm{k}$ of cement mortars.

The following scenario is about a construction exposed to natural carbonation [8]. According to EN206-1 [2] the reinforcement cover $\left(\mathrm{c}_{\text {min,dur }}\right)$ is $25 \mathrm{~mm}$ for concrete structures exposed to XC2 class (mixtures $\mathrm{C} 1, \mathrm{C} 3$ and $\mathrm{C} 5$ ) and $35 \mathrm{~mm}$ for mixtures exposed to $\mathrm{XC} 4$ class (mixtures C2, C4 and C6),. Table 12 and Figure 5 present the time needed for carbonation to reach the reinforcement in each of the 6 concretes.

Table 12. Service life (initiation period) of concrete mixtures prepared (years).

\begin{tabular}{|c|c|c|c|c|c|c|}
\hline Life Time & C1 & C2 & C3 & C4 & C5 & C6 \\
\hline years & 25 & 77 & 22 & 57 & 7 & 46 \\
\hline
\end{tabular}

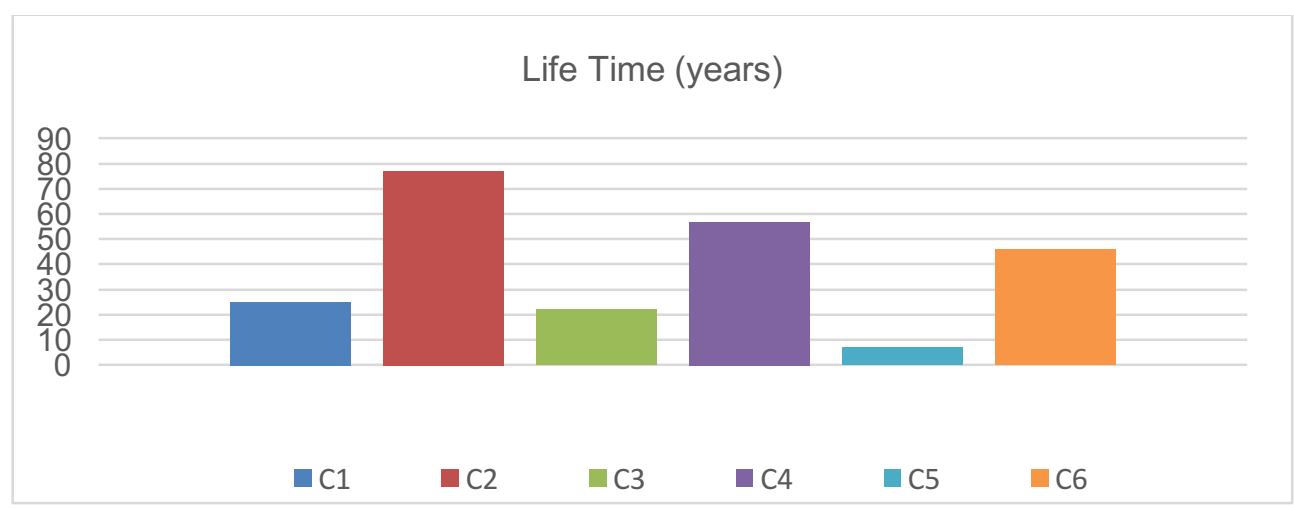

Fig. 5. Service life against carbonation (Years).

\section{Conclusions}

Carbonation rate of concrete mixtures is significantly influenced by the type and the strength category of the cement used. Concrete mixtures produced with combinations of CEM II/A$\mathrm{M}(\mathrm{P}-\mathrm{LL}) 42.5 \mathrm{~N}$ and CEM II/B-M(W-P-LL) $32.5 \mathrm{~N}$ cements performed increased carbonation 
depth as compared with mixtures produced with CEM I or CEM II/A-M(P-LL) $42.5 \mathrm{~N}$ only. Service life or reinforced concrete structures produced with these mixtures are therefore decreased down to $60 \%$ for $\mathrm{C} 30 / 37$ mixtures and $28 \%$ for $\mathrm{C} 25 / 30$ mixtures with high w/c ratio.

The required 50 years of service life is achieved only when a mixture with high cement content and low w/c ratio is used. However even in this case the choice of cement is crucial since the combination of type II cements of different strength grades is decreasing the service life close to the limit value of 50 years.

Use of lower grade concretes produced with higher w/c ratio and lower cement content does not allow the concrete structure to achieve the specified service life irrespective of the cement type adopted.

\section{References}

1. EN 197-1 (2000)

2. EN 206 (2011)

3. EN 14630 (2006)

4. K. Sisomphon, L. FrankeCem. Con. Res. 37, 1647 (2007)

5. A Leemann, P. Nygaard, J. Kaufmann, R. Loser, Cem. Con. Comp 6233 (2015)

6. R. Neves, F. Branco, J. de Brito, Cem. Con. Comp. 419 (2013)

7. M. Tarek Uddin, Md. Nazrul Islam, S. Kumar Sutradhar, M. Habibur Rahman Chowdhury, A. Hasnat, J. M. Khatib, Third International Conference on Sustainable Construction Materials and Technologies 1 (Kyoto, Japan, 2013)

8. J. Khunthongkeaw, S. Tangtermsirikul, T. Leelawat, Con. Build. Mat. 20, 744 (2006) 